\title{
Learn From Leaders \#3: Advisors and Mentors
}

\author{
Jon Eckhardt (University of Wisconsin-Madison) \\ Daniel Forbes (University of Minnesota, Carlson School of Management)
}

KEYWORDS: Startups, mentors, advisory, Learn From Leaders.

\author{
ets/learn-from-leaders)
}

This is the third video in our exclusive series called "Learn from Leaders," featuring advice for early-stage entrepreneurs and innovators from founders and CEOs of groundbreaking companies. Each of our Learn from Leaders videos focuses on an important step in launching a company. In this one, the founders and CEOS discuss how mentors and carefully chosen advisors helped them shape their ventures and make sound decisions.

Our interview subjects include Linda Hall, former CEO of MinuteClinic; Scott Nash, founder of Mom's Organic Market; Seth Goldman, founder of Honest Tea; Jeff Freeland-Nelson, founder of Yoxo Toys; and Eddie Hartmann, founder of LegalZoom.

\section{Video produced by John Buday LEARN MORE}

Explore our "Learn From Leaders" Series (https://eiexchange.com/content/learn-from-leadersfamous-founders-best-advice-for-new-ventures)

\section{LISTEN}

Listen to our original interviews with each of these leaders and others on our podcast channel on Soundcloud.

Link to video

EIX

(https://soundcloud.com/user-876519212-189256831).

Learn From Leaders: Conversations with Famous

Entrepreneurs

(https://soundcloud.com/user-876519212-189256831/s 